\title{
Clio
}

Women, Gender, History

37 | 2013

When Medicine Meets Gender

\section{Writing the history of the relations between medicine, gender and the body in the twentieth century: a way forward?}

Delphine Gardey

Translator. Siân Reynolds

\section{(Q) OpenEdition \\ Journals}

Electronic version

URL: http://journals.openedition.org/cliowgh/404

DOI: $10.4000 /$ cliowgh.404

ISSN: 2554-3822

Publisher

Belin

\section{Electronic reference}

Delphine Gardey, «Writing the history of the relations between medicine, gender and the body in the twentieth century: a way forward? », Clio [Online], 37 | 2013, Online since 15 April 2014, connection on 22 April 2019. URL : http://journals.openedition.org/cliowgh/404 ; DOI : 10.4000/cliowgh.404 


\title{
Writing the history of relations between the body, gender and medicine in the twentieth century: a way forward?
}

\author{
Delphine GARDEY
}

The historical approach has perhaps not been uppermost in the recent turn taken by the social sciences towards analysing how the body and gender relate to science and medicine. ${ }^{1}$ When, in the 1980 s, unprecedented medical technologies were developed, having farreaching medical, cultural and social effects - ultra-sound scans in obstetrics and IVF in the sphere of human reproduction, for example - they initially provoked, especially in North America, a body of feminist literature concerned with such changes and their "consequences" for women in terms of emancipation. The expressions "test-tube women", or "the mother machine" began to be heard, and questions were asked about "the future of motherhood". ${ }^{2}$ From a feminist perspective, the overall verdict was scepticism about the transformations taking place and their effects. ${ }^{3}$ These publications often convey a historical narrative which tends to identify a "before and after", and which simplifies, sometimes by idealizing it, the situation obtaining before the introduction of new technologies, which were reckoned detrimental to women's autonomy.

Danielle Chabaud-Rychter and I have previously suggested that this literature typically took the form of keeping the analysis of medical practices in a separate category from that of social relations.

\footnotetext{
1 For a suggested historical synthesis on this theme see Gardey 2013.

2 Arditti et al. 1984; Corea 1985.

3 Corea (ed.) 1985; Katz 1982 and 1989.
} 
For some time, the new technology was not studied as a subject in itself. "Commentators are not interested in its emergence, its development, or its ultimate significance and 'mode of existence". ${ }^{4}$ Characterized by taking the "view from nowhere" and by the "naïve technological determinism" prevalent in the social sciences at that time, ${ }^{5}$ these publications were missing a dimension, in the sense that they failed to investigate the direction taken by the new practices, and the ways in which bodies and identities might be implicated in this close encounter with bio-medical technology. But this deficiency has been addressed in more recent studies, which have posed questions, from both inside and outside the scientific and medical community, about the contemporary features of the relation that individuals, as social and gendered beings, may have with these innovations.

In this article, I would like to return first of all to the contribution made by three strands of research (which sometimes combine), and which have made decisive contributions to the renewal of the study of relations between the body, gender, science and medicine since the 1980s: namely the 'feminist critique of science'; Cultural Studies; and the field known as 'Social Studies of Knowledge (SSK)' [or Social Studies of Science]. My intention is to review the methods, objectives and viewpoints developed by these approaches, so as to identify their strengths and weaknesses. Having assumed this post-structuralist age of 'studies' as a context (a historically contingent one no doubt), my next step will be to identify what a historical approach could or might contribute, and to suggest some desirable directions in which research might go, when we come to write the history of the relations between the body, gender, and science in the twentieth century.

\section{Science, medical technology and gender relations as a subject of contemporary study.}

The feminist critique of science and technology

During the 1980s and 1990s, there emerged in the United States what might be termed a "generalist" feminist critique of science and technology, chiefly directed against contemporary biological

4 Chabaud-Rychter and Gardey 2002: 32.

5 Wajcman 2000. 
developments and practices. Responsibility for this current of thought no doubt lies in part with a broader social movement, the Women's Health Movement, which was particularly significant in the US in the 1970s, and which witnessed campaigning by many feminists and activists on the subject of health and women's control over their own bodies. Acting as a kind of lobby, while simultaneously developing self-help health techniques and clinics, such groups were foremost in criticizing science both as a form of knowledge and as an institution, and contributed to the awareness or practice of alternative forms of health care. ${ }^{6}$

This first wave of feminist critiques of science $^{7}$ gradually defined its own field of study, preparing the way for a broader epistemological program, which would lead on one hand to "standpoint theory", ${ }^{8}$ that is identifying the position from which knowledge was gained and delivered, and on the other hand to a large number of empirical studies concentrating on scientific and/or biomedical objects, questions and situations, and issues relating to gender.

In parallel with this movement focusing largely on science, other feminist approaches to science and medical technologies accompanied and contributed to the emerging field of Cultural Studies. This literature drew on anthropology and post-modern philosophy, and essentially proposed an analysis of technology as text or medium. It found expression in many works, notably on the dominant social and cultural phenomena of the period, for example techniques of visualizing / scanning of the body, and human reproduction. ${ }^{9}$ A dominant feature of the cultural studies approach has been to concentrate the analysis more firmly on discourses and images, but also on the employment and "consumption" of biomedical techniques, rather than on the logic of origins and

6 Löwy 2005; Fausto-Sterling 2000.

7 Ardener (ed.) 1978; Birke 1986; Bleier (ed.) 1984; Fausto-Sterling 1985; FoxKeller 1984; Gardey and Löwy 2000; Gardey 2005.

8 Haraway 1988a; Hartsock 1997; Harding 1991 and 2003.

9 Adams 1994; Cartwright 1995. 
innovation, or the logic governing the working assumptions of professionals engaged in the bio-medical sphere.

In this literature, since many feminists were then working on the history and anthropology of the sciences, identities and bodies were no longer considered as given, pre-existing frameworks, or simple facts, but as acting and acted upon, in their relation to technology. Donna Haraway, who worked at the intersection of these various currents, played a key role in opening up the spectrum of what might be deconstructed in terms of "the natural", but also because she proposed a reading of bio-medical technologies as tools for the renegociation of identities. She was one of the first feminist writers to realize the scale of the transformations that were taking place in the life sciences, as these new bio-techniques were developed, and to link these changes to other orders: technological, material, economic and symbolic. Her work interrogates the forms of experience in the techno-scientific context, and considers the ways in which the definition of the subject and his/her environment, of sex and gender, of the human and the artefactual, is renegotiated in the context of genetic engineering and the new technology of reproduction and virtual reality. ${ }^{10}$ She was also a pioneer in pointing out the path towards seizing the opportunities made possible by such changes, by reading the de-stabilizing of sex and gender as a space for "promise", agency, and possible emancipation'. ${ }^{11}$

The "deconstruction" of bodies and identities has been been on the agenda for historical, anthropological and/or feminist thought in a general sense since the $1990 \mathrm{~s} .{ }^{12}$ Women historians, especially those working on the modern period, ${ }^{13}$ played a key role in deconstructing the idea that the body is biologically given, and in revealing how "natural facts" about bodies and sexual identities are sometimes directly produced not only by medical discourses and practices, but also by medical institutions. The work of Nelly Oudshoorn, Lara

\footnotetext{
10 Haraway 1985, 1988a, 1988b.

11 Gardey 2012.

12 Gardey 2006.

13 Duden 1993; Park 1996; Jordanova 1989; Schiebinger 1989; Akrich \& Laborie 1999.
} 
Marks and Bernice Hausman has provided striking examples from the twentieth century, of which more below.

The "descriptive turn" in the social sciences: the social studies of knowledge and the plasticity of the theory of gender.

The 1990s saw the end of grand narratives and macro-social interpretations. Haraway's prophecies, fabulations and fictions, which proposed a political reading of the contemporary, were in this sense highly unusual, and differed from the dominant trend in social science. During the 1990s, the nebulus known as Social Studies of Knowledge (SSK) contributed to exploration of the way in which bodies, and to a lesser extent gender identities, could be transformed in their relation to medical technology and knowledge. Becoming objects in themselves, these states of bodies and gender are above all envisaged as work-in-progress, negotiable conditions, configurations which have to be decoded by fine contextual analysis, borrowing from ethnomethodology or developing its own analytical methodologies, as is the case for example with the development of the approach in terms of of actor-network theory (ANT). ${ }^{14}$ Here the focus is on the actors, (patients, women, health professionals) and on the medical arrangements (the network) as technical arrangements. The perspectives developed in the wake of these programs in the 1990 s and 2000s have been essentially presentist. Their deep significance lies in the analysis of activities and the distribution of the capacities to act, in the thick description of the complexity of human/technological relations, and in the attention they have paid to the first appearance of individual techniques (the dynamics of innovation). Interpretative redeployment of this kind is always situated and localized in this work, being attentive to the plural registers of meaning, as can be seen for example in Bénédicte Champenois Rousseau's study of prenatal diagnosis, and the brilliant work of Rayna Rapp on amniocentesis. ${ }^{15}$

14 Akrich, Callon \& Latour, 2006; In this tradition, see work by Akrich \& Pasveer 1998 and Mol 2002.

15 Champenois Rousseau 2003; Rapp 2000. 
In the same way that bio-medical technology in the area of procreation and trans-sexuality has created the possibility of rendering bodies (and sexual identities) more fluid, theories and conceptualizations of gender have also become more "plastic". This can be seen in West and Zimmerman's Doing Gender, or the conceptualization of gender as "performance" by Judith Butler. ${ }^{16}$ This notion of a plasticity in individuals' conditions and experiences is interesting in terms of what it makes possible in the way of emancipation and agency. The "pragmatic and descriptive turn" in the social sciences has thus contributed to producing studies which lay emphasis on local and situated versions of the empowerment of agents, even in restrictive configurations, as proposed for example by Madeleine Akrich, who examined the relation of women giving birth to the technical apparatus surrounding childbirth. This tool would therefore be an appropriate one with which to describe a certain historical reality in which there would be a wide range of possibilities (inevitably bio-technological and social) for the lived experience of parenthood/kinship, sexuality, and handicap.

The reversal of stigma, and the use of the "precarity"17 of a condition, as a resource enabling people to act and work together whether the precarity is the result of a "choice" (of sex or sexuality, in the cases of trans-sexualism and homosexuality) or linked to a health problem (as in the case of campaigns by handicapped people, or patients linked by a serious or rare illness) appears to be a new phenomenon emerging in the late twentieth century. It means focusing the debate on the wider medical, social and political arena, as much as on the content of the scientific knowledge which can or ought to be produced. It may also concern the types of therapy or treatment with which the patient may or should be treated, and finally the social and political rights which may result from a "precarious" condition.

\footnotetext{
16 West \& Zimmerman 1987; Butler 2006 [1999].

17 Butler 2009
} 


\section{Agency, neoliberalism and post-modern promises?}

It is possible to imagine another reading of these very contemporary transformations, as much in the way they have been investigated as in the way they have been lived collectively, since structurally, they have broadly coincided with a certain conjuncture of economic and social relations, which has also become identified as an age of managerialism and capitalism. ${ }^{18}$ Bio-technological promises are promises made to the individual: they appear to be resources which he or she may or may not employ, to enhance his/her sexual performance or fertility, to extend the limits of fertility, or of the sexual characteristics of one's body. ${ }^{19}$ Studies produced in the framework of SSK have not aimed to take account of more structural questions of power or imbalance. They are not concerned with envisaging the benefits of technology as they affect the groups concerned: particular groups of patients for example, groups of health professionals, or individual bio-medical companies.

Nor has the eminently localized and Western-centric, and later delocalized and centripetal nature of the rise of bio-medical technology of the last thirty years been questioned by the "Cyborgian" turn characteristic of certain authors in the field of cultural studies of the 1990s and 2000s. The "cyborg" moment (which occurs in feminist theory too) outlines a fictional or futurist version of the contemporary, in which new forms of disembodiment are praised, as are the joys of the redeployment of sexual identities, the challenging of the heterosexual and reproductive matrix, and disturbances to sexuality, reproduction, and parenthood. ${ }^{20}$ This was a time when transvestism, plastic surgery, prostheses (including those of a sexual nature), sex changes, and the "commodification" of the self, became more open and frequent. The "cyborg" moment - and one should recognize that it had a socially effective impact, notwithstanding some actual fiction - appears as a moment, an unusual one, true, in the deconstruction of the discursive and material limits of gender and

\footnotetext{
18 Boltanski \& Chapiello.

19 More generally on the productivity (psychic and physical) of subjects deemed necessary in the late twentieth century, Eherenberg (1991) and Queval 2004.

20 Balsamo 1992 and 1996; Featherstone \& Burrows 1996; Braidotti 1996.
} 
the body, and therefore one of opportunities; but it also coincided with a phase of neoliberalism in which the enhancement, commodification, ${ }^{21}$ or indeed productivity of the individual became economic and social imperatives. In this contemporary age of relations between gender, body and bio-medicine, it becomes the individual's responsibility to "draw on" technological "resources" or "solutions", whose genealogy and configurations are not necessarily questioned, but which are redefining, normatively and in a very powerful way, what social existence (and the gender relations within it) can and ought to be. ${ }^{22}$

\section{The normative, the political, and the current transformations}

This period is therefore paradoxical. Essentially, the literature so far produced around the subject of bio-technology has been agnostic as to the collective consequences that might be expected, and has refrained from formulating normative hypotheses about the current transformations it has brought about. This desire to suspend judgment as overly global or macro-social comment on what is happening is assumed for example in the work of anthropologist Marilyn Strathern, ${ }^{23}$ when she applies herself to the "reconfigurations of kinship" as a result of the development of new technologies of reproduction. This manner of relativizing the nature of the transformations at work emerges from observation itself, since Marilyn Strathern shows that in spite of a focus on technology and bio-genetics, the new forms of reproduction tend to create situations disconnected from biological parenthood, and thus to widen kinship relations.

Apparently holding little interest for the social sciences specializing in the study of science and biomedical technology, normative questions have essentially been handled by the field of bioethics, which tends to define the limits of "the right questions" in sometimes rather exclusive ways. Whether concerned with the

\footnotetext{
21 Commodification, in the sense of transforming something into a commodity: marketing of the self, as in genetic engineering.

22 Akrich et al. 2008.

23 Stratherm 1992.
} 
regularizing of sperm donation, organ donation, the treatment and care of terminal patients, or medical practices consequent on the development of pre-natal diagnosis, the bio-ethical approach may completely abstain from considering social or gender relations, or the question of power. ${ }^{24}$ One can however point to a tradition in French moral sociology, and in particular the research by Simone Bateman. ${ }^{25}$ Her work has developed an empirical approach to ethical questions on assisted reproduction, on which she is one of the leading French specialists. Although questions to do with gender have not been a central focus of her work, they are tending to become more apparent. Additionally, and out of step with "traditional" feminist attitudes towards abortion, the positing of the sociology of engendering based on a (moral and political) reflexion on the foetal condition, as proposed by Luc Boltanski, no doubt marks a significant moment of reconfiguration in a double perspective, historical and normative. ${ }^{26}$

\section{Beyond the present situation of gender-body-medecine relations: the arguments of history}

Reviewing the strengths and limitations of these different literatures, situating them and giving them a place in the history of social science, and of history itself, means reviewing the conditions in which it might be possible to write a history capable of giving a substantial account of the transformations affecting bodies and gender identities in the long twentieth century. It also entails reminding ourselves that, no more in history than in other disciplines, is there any form of questioning or standpoint which is completely detached from an intellectual and epistemological context, itself linked to a given social and political environment. One feature of contemporary life is that social and sexual identities are, more than in the past, conditioned by bio-medical resources and technology. The transformation of what is defined and counts as society, the taking into consideration of science

24 Unlike in the United States, there is not (yet) in France a recognized field of feminist ethics or bioethics.

25 Bateman 1991 and 1998.

26 For a discussion of Boltanski's ideas, see the debate which I edited in Travail, Genre, Sociétés, 2006. 
and technology in the make-up of social relations, is one of the most obvious contributions of SSK and the social history of science and technology. ${ }^{27}$ How are we to give a historical account of such a transformation, and to do so using a gendered perspective? What would it change in society and in gender relations, if bio-medical technologies were increasingly engaged in what defines the social? How can one describe the place of science and technology in the everyday life of men and women in the twentieth century, without over- or under-estimating the importance of the turning taken in the 1980s and its possible radical charge? And how can we do all this by maintaining not only a gendered perspective but a feminist one?

\section{Tracing genealogies, describing new events}

Historical research can firstly offer the chance to redefine the dynamics of the subject of study; making it possible to see lines of descent and genealogies, and to locate the subject in a longer chronology (la longue durée); this enables us to distinguish between transformation, irreversibility, and mere adjusting of former practices and behaviour. As the study of transvestism/cross-dressing has suggested, ${ }^{28}$ the chief interest of the historian is both to question the "natural" character of the evidence presented, and to question the certainty every generation feels of the novel character of its experiments. And yet there are contexts in which a historical break occurs. In this case, Bernice Hausmann has argued, with a convincing amount of detail, that "transsexuality" embodies a clear break with the repertoire of previous practices. The medicalization of transsexuality between the world wars, followed by the medical takeover of the condition in the US in the 1950s, are part of the emergence of the medical technology for and knowledge about sex change, as well as the social condition of the transsexual individual. Both the physical intervention and the psychiatric and medical treatment concerned are unprecedented (which is not to say that they do not result from decades of previous medical experiment.) And in that sense, they have a double effect: the experience of transsexuality,

\footnotetext{
27 A pioneering article in French was Pestre's (1995).

28 Bard \& Pellegrin 1999.
} 
as a condition produced by medical intervention, is a new one; and the condition of the "trans" or "intersex" individual is modified, since the "medical and social supply side" also becomes a normative constraint, leading for example to an increase in the number of operations of "reattribution" of the sex assumed at birth. In this case, unquestionably, certain frontiers have been moved and resituated. It is true that experience of these new forms of subjectivity is still confined to a limited number of individuals, but its social impact, and what it has helped to redefine, from the strict point of view of gender history, may be regarded over the long term as a distinct event.

Among the lines of research which such history could propose and develop would be: locating and explaining the repetition of "events", the accumulation of expertise, the convergence of practice, the hybridization of the technology, the diversification and specialization of professional fields and medical specialisms, but also the simultaneous emergence of supply and demand (for contraception, treatment of the menopause/HRT, sexual dysfunction problems, and plastic surgery for aesthetic reasons). ${ }^{29}$ This history would be concerned with the content of scientific and medical practices and aims, to the extent that they are handled by professional milieus, yet are at the same time matters of wider social and cultural debate. Adele Clarke's work, ${ }^{30}$ although at first sight principally limited to the institutional, professional and cognitive dynamics shaping the new field of reproductive science, in fact fits very well into such a program, from the point of view of women's and gender history. This research shows - and the evidence had not been studied before - that the first test-tube baby did not come from nowhere, but was the result of scientific investment beginning as early as 1910, and of alliances implicating wider circles, with contributions made not only by the relevant sciences and the disciplines one would expect, but by other branches of medicine ( among them veterinary science, which was particularly important between 1920 and 1960, or eugenics, which brought together certain demographers and biologists in the inter-war period), as well as non-scientific milieux

29 Fishman 2004; Hirt 2009; Löwy 2006.

30 Clarke 1998. 
(philanthropic, business, neo-Malthusian, feminist) - all contributing to the social, political, and eventually epistemological context for IVF research. Lara Marks's work ${ }^{31}$ on the history of the contraceptive pill has been complementary to some of the situations and issues pinpointed by Adele Clarke. Both of them have for example underlined the significance of Margaret Sanger ${ }^{32}$ in the invention of the idea of a "universal contraceptive", the quest for institutional, intellectual and financial resources and alliances as well as purely scientific ones, and her contribution to the shaping of scientific agendas and environments which might aid the feminist cause, as well as a certain conception of social emancipation.

\section{Stating temporalities and contexts, reconsidering certain topics, producing new narratives}

Genealogical analysis carried out on certain very contemporary subjects can enable us to analyse the contexts in which they first saw the light, and to describe what has really been transformed in the period dating from the late twentieth century. We can see for example, how an "industrial time" in the reproductive sciences (19501970), dominated by the imperatives of norm-creation, regulation and treatment, gave way, once IVF technology had been launched, to an unprecedented expansion of interventionist processes and products in the domain of human reproduction. The rapid expansion of actions and capacities in the way of manipulating living beings, is a question well worth exploring beyond the central themes of reproduction and sexuality, especially from a feminist perspective. ${ }^{33}$

Symmetrically, this "fin de siècle" moment prompts us to think about the preceding periods. Should we identify a different "industrial" period of relations between bodies/products/medical technologies, and if so what should we call it? Should we speak of an "endocrine" period, starting in the 1920s and becoming visible

\footnotetext{
31 Marks 2001

32 Margaret Sanger (1879-1966) was an American birth control campaigner who played a decisive role in the history of the movement, and in the coming of the contraceptive pill.

33 Franklin \& Ragoné 1998
} 
through the proliferation of medications in the inter-war period? ${ }^{34}$ And then of a "chemical" time, during which not only endocrinal applications but also major industrial developments with vaster environmental consequences would come into play, for example those associated with the agro-alimentary industry, or the more general modification of the environment though toxic substances (such as hormone changing chemicals). This reading (via a history of toxicity) has been proposed in the US by Nancy Langston. ${ }^{35}$ She has drawn attention to certain health scandals (e.g. the Distilbene years) which had gendered effects that have remained in people's memories. ${ }^{36}$ An approach of this kind would make it possible to reconcile different historiographies: the classic history of industrial hazards, and the way both men and women have been affected by them, depending on the sectors in which they have worked, a history which has yet to be written, in large part, for the long twentieth century; ${ }^{37}$ and a new social history of health which would have gender as one of its central axes. ${ }^{38}$

The spectrum of subjects that might be reconsidered in this perspective is very wide. What for instance would the chronology look like of the social and medical history of the conditions of maternity (pregnancy and childbirth) in twentieth-century Europe? How would we, these days, write the history of male and female sterility? ${ }^{39}$ How should we re-examine the histories of the major aetiological changes of the twentieth century from a gendered perspective? What is the significance of revisiting the history of an

34 Oudshoorn 1994.

35 Langston 2010.

36 In 1971, researchers in Boston uncovered the link between cancers in very young women whose mothers had taken during pregnancy the drug Distilbene, which contained a synthetic oestrogen Des or diethylstilbestrol. Among the 2 to 5 million children exposed to DES in the womb, it has been estimated that $95 \%$ later suffered reproductive abnormalitites, such as irregular menstruation, infertility and the risk of cancer, ibid., p., 18.

37 For recent contributions to new studies on these subjects see Clark? 1997; Bruno \& Omnès 2004.

38 See the interesting synthesis on the US by Apple 1990.

39 Pfeffer 1993. 
illness defined as feminine in the nineteenth century (phthisis) but which had no gendered indication or specificities when it was redefined as tuberculosis in the twentieth century? How should we consider, over the long term, the place taken by medical treatment and institutions in people's daily lives? How should we envisage the relationship between bodies, gender and medicine in the twentieth century, taking account of the development of public health policies, and the way they target and define certain sectors of the public. Research into the "control of bodies" 40 means considering the State, hospital infrastructures, medical institutions, and types of pubic intervention. It questions the roles of the various actors/agents engaged in the definition of medical supply and health policy (the public authorities, health professionals, industrialists supplying these sectors.) The economy of these relations was profoundly transformed in the course of the twentieth century, and this history directly concerns the possibilities of access to treatment, or to medical infrastructures: examples would be the termination of pregnancy, and whether or not it is reimbursed; campaigns to prevent the spread of AIDs; or the need to apply to private agencies or to a hospital establishment to benefit from sperm donation. ${ }^{41}$ The history of the market in sex hormones tells us that hormonal solutions started becoming available to a 'public' consisting of menopausal women as early as the inter-war period, but what is there to say about contemporary practices now witnessing the emergence of markets for 'consumers' rather than patients, markets which have been directly shaped by the pharmaceutical industry in the sense of the 'commodification' of female desire and the medicalization of treatments for sexual dysfunction? ${ }^{42}$

It is clear that there is a strong case for undertaking many more micro-historical surveys in the French and European context, so as to be able to account for the dynamics at work, and for what is specific about them. The topic of the circulation and appropriation of medical practices and techniques (e.g. the history of the contraceptive pill, the

\footnotetext{
$40 \quad$ Fassin \& Memmi 2004.

41 Becker 2000

42 Fishman 2004.
} 
prevalence of "medical tourism" in the history of abortion, or of surrogate motherhood today, the possibility of access to some medication via the internet) reminds us of the complexity of contexts which remain basically anchored in legal and institutional frameworks conditioned by specific scientific, political, economic and social factors.

\section{Revealing what is at issue in normative and political terms}

While we need more case-studies, we need them to be carried out in a way that recognizes the contribution of contemporary social science. It seems desirable to avoid as far as possible simplistic readings, or the logic of 'effects' and determining factors and to avoid repeating a division between a separate artificial field covering the social (or gender), and a different (sacrosanct) field of 'hard science' and technology. Historical research can and should draw on resources from the social study of science and medicine, and critical and feminist theory. Researchers will find that these offer valuable tools to help identify or analyse the logic peculiar to the different agents, the contingent and local meaning that scientific facts may hold for certain human groupings, and the way experience is modified by contact with medical technology.

A historical approach in any case has its own resources to draw on. By seeking to locate key contexts, moments, and turning-points, by identifying differentiated 'regimes' in which economic and political questions are taken seriously, ${ }^{43}$ by uncovering the genealogy of certain practices, by studying the scientific and social controversies aroused by certain innovations, history enables us to see the alternative paths which existed in the past, and thus those which exist in the present. Opening up space for alternatives, by revealing the social and gender issues which are present when scientific or medical choices are made, or inversely, showing how medical and technological responses appeared in the course of the twentieth century as socially acceptable responses, is a legitimate aim both for academic research and for the wider society. Donna Haraway suggests that the ability to produce narratives that help us define the

43 Pestre 2003. 
boundaries of choice is one of the normative constraints which we are entitled to expect from academic science and scientific pronouncements.

I have attempted in this article to show how the 'descriptive turn' in the social sciences, and the crisis in more structuring systems of interpretation, has probably weakened critical readings of certain phenomena, and that history should therefore have a place in the new reconfiguration of knowledge, because it can help reveal the alternative pathways, the local significance of case studies, but also the wider global framework in which individual and social experience can be inscribed into the long term of the history of the relation between human bodies on one hand, and medical knowledge and institutions, political and economic life, and medical practices on the other.

Translated by Siân Reynolds

\section{Bibliography}

Adams Alice, 1994, Reproducing the Womb: Images of Childbirth in Science, Feminist Theory, and Literature, Ithaca, Cornell University Press.

Akrich Madeleine \& Françoise Laborie (dir.), 1999 « De la contraception à l'enfantement. L'offre technologique en question », Les Cabiers du Genre, 25, p. 17-48.

Akrich Madeleine \& Bernike Pasveer, 1998, Comment la naissance vient aux femmes, Paris, Les empêcheurs de penser en rond.

—, 2004, «Embodiment and Disembodiment» in Childbirth Narratives, Body \& Society. Special Issue on Bodies on Trial, 10, p. 63-84.

Akrich Madeleine, Callon Michel \& Bruno Latour, 2006, Sociologie de la traduction. Textes fondateurs, Paris, Presses des Mines de Paris.

Akrich Madeleine, Gardey Delphine, Löwy Ilana \& Antoine Picon, 2008, "Corps, genre, techniques, identités », in Dominique Pestre (dir.), "Science et devenir de l'homme », Les Cabiers du Mouvement Universel de la Responsabilité Scientifique, 57/58, p. 70-91.

Apple Rima, 1990, Women, Health and Medicine in America, New Brunswick New Jersey, Rutgers University Press.

Ardener Shirley (ed.), 1978, Defining Females. The Nature of Women in Society, London, Croom Helm. 
Arditti Rita, Klein Renate Duelli, Minden Shelley (eds), 1984, Test-Tube Women: What Future for Motherhood?, London, Pandora Press.

Balsamo Ann, 1992, «On the Cutting Edge: Cosmetic Surgery and the Technological Production of the Gendered Body ", Camera Obscura, 28, p. 207-238.

—, 1996, Technologies of the Gendered Body: Reading Cyborg Women, Durham, NC, Duke University Press.

Bard Christine \& Nicole Pellegrin (dir.), 1999, «Femmes travesties : un mauvais genre », Clio. Histoire, Femmes et Societés, 10.

Bateman Simone (dir.), 1991, Biomédecine et devenir de la personne, Paris, Le Seuil.

—, (dir.), 1998, "La bioéthique comme objet sociologique», Cabiers internationaux de sociologie, 104, p. 5-32.

Becker Gay, 2000, «Espoir à vendre : commercialisation et consommation de techniques d'assistance médicale à la procréation aux États-Unis », Sciences Sociales et Santé, 18/4, p. 105-126.

Birke Linda, 1986, Women, Feminism and Biology. The Feminist Challenge, Brighton, Harvester Press.

Bleier Ruth (ed.), 1984, Science and Gender: A Critique of Biology and Its Theory of Women, New York, Pergamon Press.

Boltanski Luc, 2004, La condition fotale. Sociologie de l'engendrement, Paris, Gallimard.

Boltanski Luc \& Ève Chiapello, 1999, Le nowvel esprit du capitalisme, Paris, Gallimard.

Braidotti Rosi \& Nina Lykke (eds), 1996, Between Monsters, Goddesses and Cyborgs: Feminist Confrontations with Science, Medicine and Cyberspace, London, ZedBooks.

Bruno Anne-Sophie \& Catherine Omnès, 2004, Les mains inutiles. Inaptitude au travail et emploi en Europe, Paris, Belin.

Butler Judith, 1990, Gender Trouble: feminism and the subversion of identity, New York, Routledge.

—, 2009, Ce qui fait une vie. Essai sur la violence, la guerre et le deuil, Paris, Zones. Trad. de Joëlle Marelli.

Cartwright Lisa, 1995, Screening the Body: Tracing Medecine's Visual Culture, Minneapolis, The University of Minnesota Press.

Chabaud-Rychter Danielle \& Delphine Gardey (dir), 2002, L'engendrement des choses. Des hommes, des femmes et des techniques, Paris, Éditions des archives contemporaines. 
Champenois Rousseau Bénédicte, 2003, «Éthique et moralité ordinaire dans la pratique du diagnostic prénatal, thèse de sociologie », École Nationale Supérieure des Mines de Paris.

Clark Claudia, 1997, Radium Girls: Women and Industrial Health Reform, 19101935, Chapel Hill, University of North Carolina Press.

Clarke Adele, 1998, Disciplining Reproduction: Modernity, American Life and the Problem of Sex, Berkeley, California University Press.

Corea Gena (ed.), 1985, Man-Made Women: How New Reproductive Technologies Affect Women, London, University of Indiana Press

Corea Gena, 1985, The Mother Machine, New York, Harper \& Row.

Duden Barbara, 1993, Disembodying women: perspectives on pregnancy and the unborn, Cambridge, Cambridge University Press.

Ehrenberg Alain, 1991, Le culte de la performance, Paris, Calmann-Lévy.

Fassin Didier \& Dominique Memmi, 2004, Le gowvernement des corps, Paris, Éditions de l'EHESS.

Fausto-Sterling Anne, 1985, Myths of Gender: Biological Theories about Man and Woman, New York, Basic Books.

-,2012, Corps en tous genres: la dualité des sexes à l'épreuve de la science, La Découverte/Institut Émilie du Châtelet (translated from Sexing the Body Gender Politics and the Construction of Sexuality, New York, Basis Books, 2000).

Featherstone Mike \& Roger Burrows (eds.), 1996, Cyberspace, Cyber Bodies, Cyber Punk: Cultures of Technological Embodiement, London, Sage.

Fishman Jennifer, 2004, "Manufacturing Desire: the Commodification of Female Sexual Dysfunction », Social Studies of Science, 34/2, p. 187-218.

Fox-Keller Evelyn, 1984, Reflections on Gender and Science, New Haven, Yale University Press.

Franklin Sarah \& Helena Ragonè (eds.), 1998, Reproducing Reproduction: Kinship, Power and Technological Innovation, Philadelphia, University of Pennsylvania Press.

Gardey Delphine, 2005, «La part de l'ombre ou celle des Lumières: les sciences et la recherche au risque du genre ", Travail, Genre et Sociétés, 14, p. 29- 47.

—, 2006, «Les sciences et la construction des identités sexuées. Une revue critique », Annales. Histoire, Sciences Sociales, 3, p. 649-673.

—, 2009, «Au cœur à corps avec le Manifeste Cyborg de Donna Haraway », Esprit, 353, mars-avril, p. 208-217. 
—, 2010, "Bruno Latour: Guerre et Paix, tours et détours féministes », in Danielle Chabaud-Rychter, Virginie Descoutures, Anne-Marie Devreux \& Eleni Varikas (dir.), Sous les sciences sociales, le genre. Relectures critiques de Max Weber à Michel Foucault, Paris, La Découverte, p. 203-218.

—, 2013, "Genre, corps et biomédecine au $\mathrm{xx}^{\mathrm{e}}$ siècle », in Christophe Bonneuil \& Dominique Pestre (dir.), Histoire des sciences modernes, vol. 3 : 1914-2014, Paris, Le Seuil.

Gardey Delphine (dir.), 2006, "Controverse » sur le livre de Luc Boltanski, La condition fretale. Sociologie de l'engendrement, dans Travail, Genre et Sociétés, 15, p. 173-217.

Gardey Delphine \& Ilana Löwy (dir), 2000, L'invention du naturel. Les sciences et la fabrication $d u$ féminin et $d u$ masculin, Paris, Éditions des archives contemporaines.

Haraway Donna, 1985, «A Manifesto for Cyborgs: Science, Technology, and Socialist Feminism in the 1980s », Socialist Review, 15, p. 65-107

—, 1988a, "Situated Knowledges: The Science Question in Feminism and the Privilege of Partial Perspective », Feminist Studies, 14/3, p. 575-599_ , 1988b, Simians, Cyborg, and Women: The Reinvention of Nature, London, Free Association Books, 2007, Manifeste cyborg et autres essais. Sciences, fiction, féminisme, Paris, Exils.

Harding Sandra, 1991, Whose Science? Whose Knowledge? Thinking from Women's Lives, Ithaca, New York, Cornell University Press.

-, (ed.), 2003, The Feminist Standpoint Theory Reader: Intellectual and Political Controversies, New York, London, Routledge.

Hartsock Nancy C.M., 1997, The Feminist Standpoint Revisited and Other Essays, Boulder Colorado, Westview Press Inc.

Hausman Bernice, 1995, Changing sex, transsexualism, technology and the idea of gender, Durham-London, Duke University Press.

Hirt Caroline, 2009, «La sexualité postnatale : un objet d'étude négligé par les sciences humaines et sociales ", in Catherine Deschamps, Laurent Gaissad \& Christelle Taraud (dir.), Hétéros : discours, lieux, pratiques, Paris, EPEL, p. 145-153.

Jordanova Ludmilla, 1989, Sexual visions. Images of gender in science and medicine between the eighteenth and twentieth century, Madison, The University of Wisconsin Press.

Katz Barbara, 1982, In labor: Women and Power in the Birthplace, New York, Norton \& Co. 
—, 1989, Recreating Motherhood Ideology and Technology in a Patriarcal Society, New York, London, Norton.

Langston Nancy, 2010, Toxic Bodies, Hormone disruptors and the legacy of DES, New Haven \& London, Yale University Press.

Löwy Ilana, 2000, «Assistance médicale à la procréation et traitement de la stérilité masculine en France », Sciences sociales et santé, 18/4, p. 75-102.

—, 2005, «Le féminisme a-t-il changé la recherche biomédicale ?», Travail, genre et sociétés, 14 , p. 89-108.

Marks Lara, 2001, Sexual Chemistry: A History of the Contraceptive Pill, Yale, Yale University Press.

Mol Anne-Marie, 2002, The Body Multiple. Ontology in Medical Practice, Durham, Duke University Press.

Oudshoorn Nelly, 1994, Beyond the Natural Body: Archeology of Sex Hormons. London, Routledge.

Park Katharine, 1996, "The rediscovery of the clitoris: French medicine and the tribade (1570-1620) », in Carla Mazzio \& David Hillman (eds), The body in part: Discourses and anatomies in Early Modern Europe, New York, Routledge.

Pestre Dominique, 1995, "Pour une histoire sociale et culturelle des sciences. Nouvelles définitions, nouveaux objets, nouvelles pratiques », Annales. Histoire, Sciences Sociales, 50/3, p. 487-522.

—, 2003, Science, argent et politique. Un essai d'interprétation, Paris, INRA Éditions.

Pfeffer Naomi, 1993, A Political History of Reproductive Medicine, Cambridge, Polity Press.

Queval Isabelle, 2004, S'accomplir on se dépasser, essai sur le sport contemporain, Paris, Gallimard.

Rapp Rayna, 2000, Testing Women, Testing the Fetus: The Social impact of Amniocentesis in America, New York, Routledge.

Strathern Marilyn, 1998, « Making Miracles: Scientific Progress and the Facts of Life », in Sarah Franklin \& Helena Ragonè (eds), Reproducing reproduction, Kinship, power and Technical innovation, Philadelphia, University of Pennsylvania Press, p. 102-113.

Schiebinger Londa, 1989, The mind has no sex? Women in the origins of modern science, Cambridge, Harvard University Press.

Vuille Marilène, 1998, Accouchement et douleur. Une étude sociologique, Lausanne, Antipodes. 
Wajcman Judy, 2000, «Reflections on gender and technology studies In what state is the art? ", Social Studies of Science, 30/3, p. 447-464.

—, 2004, Technofeminism, Cambridge, Polity Press.

West Candace \& Don H. Zimmerman, 1987, «Doing gender », Gender and Society, 1/2, p. 125-151. 